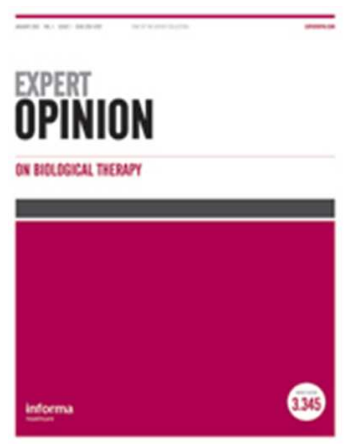

Please download and read the instructions before proceeding to the peer review

Cetuximab for treating non-small cell lung cancer

\begin{tabular}{|r|l|}
\hline Journal: & Expert Opinion On Biological Therapy \\
\hline Manuscript ID & EOBT-2017-0121 \\
\hline Manuscript Type: & Review \\
\hline Keywords: & $\begin{array}{l}\text { Cetuximab, Non small cell lung cancer, Predictive biomarkers, Combination } \\
\text { trials }\end{array}$ \\
\hline
\end{tabular}

SCHOLARONE ${ }^{\mathrm{m}}$

Manuscripts 


\title{
Cetuximab for treating non-small cell lung cancer
}

\author{
Luca Mazzarella, Alessandro Guida, Giuseppe Curigliano*
}

Istituto Europeo di Oncologia, Division of Early Drug Development for Innovative Therapies, Via Ripamonti 435, 20141 Milano, Italy

\author{
*Correspondence to: \\ Giuseppe Curigliano, MD, PhD, \\ Istituto Europeo di Oncologia, \\ Division of Early Drug Development for Innovative Therapies \\ Via Ripamonti 435, 20141 Milano, Italy \\ $\mathrm{T}+39-02-57489439 \mathrm{~F}+39-02-94379224$ \\ Email: giuseppe.curigliano@ieo.it
}

\section{Abstract}

Introduction: Cetuximab is a mouse-human chimeric antibody directed against the Epidermal Growth Factor Receptor (EGFR). EGFR-dependent signaling plays a crucial role in epithelial cancer biology, so several anti-EGFR agents have been developed. Cetuximab was the earliest and after about two decades it gained a place in the management of advanced colorectal and head and neck cancers, whereas it has had a tough time in Non Small Cell Lung Cancer (NSCLC), where despite statistically significant phase III trials, the clinical benefit observed was marginal and insufficient to grant cetuximab approval from regulatory bodies and a place in routine clinical practice.

Areas covered: we have retrieved literature on the role of Cetuximab in NSCLC, including preclinical studies and clinical trials, focusing on recent findings.

Expert opinion: Cetuximab currently has no role in NSCLC treatment outside of research settings. We summarize the historical developement of Cetuximab research and argue that failure to identify a predictive biomarker has so far hampered its chances to enter routine practice. We identify crucial issues that should be addressed in future research, most importantly the role of EGFR amplification as predictive biomarker.

\section{Overview}

Non Small Cell Lung Cancer (NSCLC) is among the most frequent and deadliest neoplasms in western world. According to SEER estimates, incidence for lung cancer in 2016 is around 225.000 total cases in the USA, 13\% of all new cases. NSCLC accounts for $84 \%$ cases, with adenocarcinoma and squamous cell histologies accounting for $88 \%$ of all NSCLC (1). In more than $50 \%$ of the cases NSCLC presents with locally advanced or metastatic disease, where prognosis remains dismal. For stage IIIA NSCLC, 5 year survival is about 14\%, but it drops to less than $5 \%$ for IIIB and metastatic (2). When Cetuximab initiated its clinical developement in early 2000s, no targeted agent was available for NSCLC, and 
research was focused on identifying the best platinum-based doublet, which remain the cornerstone of therapy for metastatic disease to date, with the addition of radiotherapy for locally advanced disease. No real consensus has been reached for the optimal platinum companion, with taxanes, pemetrexed and vinca alkaloids as first choices (3-5). Anti-angiogenic therapy with Bevacizumab or Ramucirumab can add a moderate advantage at the price of significant toxicity and can be added in selected patients $(3,5-7)$. Targeted therapy has gained an important role in NSCLC, with the approval of two main classes of drugs. Patients with translocations involving ALK and ROS, accounting for $<5 \%$ of all NSCLC, can now be treated with oral inhibitors crizotinib, ceritinib or alectinib as monotherapy $(3,5,8-10)$. Patients with EGFR mutations, accounting for a larger share (up to $18 \%$, with wide variations across nations (11)) are treated with EGFR tyrosine kinase inhibitors (TKI) erlotinib, gefitinib or the 2nd generation afatinib in the first line. All these compounds provided advantages in progression-free-survival (PFS) by not overall survival (OS) compared to standard chemotherapy $(3,5,12)$. Despite the variety of agents approved, the vast majority of locally advanced or metastatic tumors relapse and response rates in second line and more are still extremely low, with no agent able to provide significant improvements in survival over supportive care. Given its high mortality and incidence, there are ample margins of improvement. The arena of new drugs has widened significantly in recent years. Probably the most dramatic changes have been brought about by the introduction of immune checkpoint inhibitors, initially only in second line (nivolumab, pembrolizumab and atezolizumab) and more recently in the first line (pembrolizumab) (13-15). New agents for targeted therapy are currently in advanced developement or have recently been FDA-approved, including new targeted therapies against EGFR (dacomitinib, AZD9291, rociletinib, osimertinib and others) or other signaling pathways (MEK inhibitors like selumetinib, MET inhibitors like tivantinib and cabozantinib and others). Cetuximab is also not the only antiEGFR antibody in developement. Earlier competitors like Panitumumab and Matuzumab failed in phase 2 clinical trials $(16,17)$; Necitumumab had better success, with a recent FDA approval for the treatment of squamous cell lung cancer based on the results of the SQUIRE trial (18).

\section{Introduction to the compound}

Cetuximab began its clinical developement in the late 90 s and was among the first targeted therapies to be developed in the context of NSCLC. The impetus was the observation, a decade earlier, that many lung cancer cells express EGFR at high levels and are dependent on its signaling for growth (19-22).

\section{Chemistry}

Cetuximab was obtained by chimerization with the human IgG1 constant region of the murine fraction variable regions from myeloma cell line 225, producing an antibody that blocks the ligand-binding site of the EGFR (20-25). It has an approximate molecular weight of $152 \mathrm{kDa}$.

\section{Pharmacodynamics}

Cetuximab has high affinity to the EGFR, surprisingly higher than the original murine antibody $225(23,24,26)$. It inhibits ligand binding and ligand-mediated receptor phosphorylation, in particular on Mitogen-Activated Kinases (MAPK). In 
addition, there is also evidence suggesting that cetuximab promotes receptor internalisation, reducing the number of receptors available for interaction with the ligand $(26,27)$. Finally, there is in vitro evidence for antibody-dependent cellular cytotoxicity but no complement-mediated lysis (24). Cetuximab treatment enhances direct cytotoxicity from radio and chemotherapy(28). Combination with chemotherapy it was recently found to induce so-called immunogenic cell death (29).

Pharmacokinetics and metabolism

After 2-hour infusion of 250 and $400 \mathrm{mg} / \mathrm{m} 2$, maximum concentrations are reached $1 \mathrm{hr}$ later at 158.1 and $205 \mathrm{ug} / \mathrm{mL}$ and the elimination half lives are 71 and 75.1 hours, respectively. The volume of distribution is dose-independent and approximated the vascular space of 2 to $3 \mathrm{~L} / \mathrm{m} 2$ (30). At antibody doses in the range of 200 to $400 \mathrm{mg} / \mathrm{m} 2$, systemic clearance is saturated $(30,31)$. The PK appeared to be nonlinear in all settings analysed (30-32). Concurrent administration of chemotherapy or radiotherapy did not alter cetuximab PK (3133). Subsequent studies did not identify patient-associated variables (age, gender, body weigh, race, etc) associated with different PK and requiring dose adjustments (34).

\section{Clinical efficacy}

\section{Early phase I studies}

Two phase 1 studies established dosing for cetuximab $(31,32)$. The first, by Baselga et al, was in fact a combination of 3 trials in which cetuximab was explored as a single dose and weekly multiple doses with or without cisplatin. Doses ranged from 5 to $400 \mathrm{mg} / \mathrm{m} 2$, on a total of 52 patients. Overall, the frequency of grade 3 or higher cetuximab-related events was 1.6\%. Disease stabilizations were observed in all studies. The study with cisplatin was limited to head and neck or non-small-cell lung cancer; 69\% patients treated with antibody doses $\geq 50 \mathrm{mg} / \mathrm{m} 2$ had completed 12 weeks of therapy as planned, and 2 partial responses were observed (31). In the second study, Cetuximab was explored at doses up to $500 \mathrm{mg} / \mathrm{m} 2$ in combination with radiotherapy in patients with advanced head and neck squamous cell carcinoma. Most toxicities were associated with radiotherapy but one patient experienced grade 3 skin toxicity outside of the irradiation field at the highest dose of $500 \mathrm{mg} / \mathrm{m} 2$, which suggested the adoption of a lower dose for subsequent studies (32).

All patients achieved an objective response (13 complete, 2 partial). On the basis of these data, the recommended dose for subsequent studies was set at a loading dose of 400 to $500 \mathrm{mg} / \mathrm{m} 2$ and a maintenance weekly dose of $250 \mathrm{mg} / \mathrm{m} 2$.

\section{Clinical developement in combination with radiotherapy for stage IIIA-IIIB NSCLC}

Six phase II trials (summarized in table 1) have been conducted testing cetuximab in combination with concurrent radiotherapy with or without chemotherapy in the setting of stage III NSCLC (35-40).

Earlier single-arm studies on the addition of cetuximab to chemoradiation were promising but fairly small. However, subsequent randomized trials failed to show superiority of cetuximab addition. In the CALGB 30407 trial, 101 patients were randomized to concurrent radiochemotherapy (Pemetrexed + Carboplatin 
and radiotherapy (60 Gy) with or without Cetuximab. No significant difference was demonsrated between the two arms in terms of failure-free survival (12.3 vs 12.6 months) and OS (25.2 vs 21.2) (35). Another similarly sized randomized study, where 102 patients were randomized to receiving or not cetuximab in combination with cisplatin and radiotherapy (66Gy), also showed no benefit (40). More recently, cetuximab was tested as addition to cisplatin and vinorelbin and concurrent individualized, isotoxic accelerated radiotherapy in a single-arm phase 1 trial (41). Results were in line with previous studies, with a median OS of 21.0 months (95\% CI 19.0-22.8 months). The final word on the issue was spelled out by the RTOG 0617 trial, the largest to date. Two hypotheses were tested at the same time: whether RT dose intensification to 74 Gy was superior to standard 60 Gy and whether addition of cetuximab to the carboplatin and paclitaxel backbone was superior. Recruitment for the RT intensification hypothesis was terminated earlier due to futility but recruitment for cetuximab met its accrual endpoint and 465 patients wer available for analysis (42). Confirming the results of the earlier phase 2 trials, no OS improvement was observed with cetuximab $(25 \cdot 0$ months [95\% CI 20.2-30.5] vs $24 \cdot 0$ months [19.8-28.6]; two-sided p=0.58; HR 0.94 [95\% CI 0.74-1.19]).

An alternative approach that deserves consideration, so far tested only in 2 small nonrandomized studies, is the use of cetuximab alone with radiotherapy, in patients unfit to receive chemoradiotherapy. Jatoi et al administered cetuximab concomitant to 60 Gy RT (39), whereas Jensen et al administered cetuximab concomitant to 66 Gy IMRT and for subsequent 13 weeks (38). Median OS were 15.1 and 19.6 months respectively, which favorably compares to historical controls of similar populations treated with radiotherapy alone (43). If this approach resists the test of randomized trials, it may have some benefit in this difficult to treat population.

\section{Clinical developement for stage IIIB-IV}

\section{Phase II studies}

The first trials specifically investigating activity of cetuximab in the context of NSCLC were two small $(n=31-35)$ phase I/II trials, in combination with either paclitaxel/carboplatin (44) or gemcitabine/carboplatin (45) in the first line stage IV setting. Response rates of $26 \%$ and $29 \%$ and median OS of 11.0 and 10.2 months appeared promising. The Lung Cancer Cetuximab Study (LUCAS) was the first trial testing cetuximab in a randomized fashion, coupling it to the regimen that would later be tested for its registration study (33). Patients were randomized to receive cisplatin/vinorelbine with or without cetuximab, administered weekly at $250 \mathrm{mg} / \mathrm{m} 2$ after a loading dose of $400 \mathrm{mg} / \mathrm{m} 2$ (a schedule that has remained the standard in most studies), in 3-week cycles for a maximum of 8 cycles. The study was conducted on 86 patients without prior sample size calculation; these results appeared again moderately promising, with better response rates ( $33 \%$ vs $28 \%$ ), median PFS ( 5.0 vs 4.6 , $\mathrm{HR}=0.71$, 95\% CI 0.4-1.2) and median OS (8.3 vs 7.3 months, $\mathrm{HR}=0.71,95 \%$ CI $0.5-1.1$ ). However, unsurprisingly, no efficacy parameter was statistically significant. An additional randomized phase II study on 131 patients (BMS100) tested the addition of cetuximab to gemcitabine + cisplatin or carboplatin. Again, there were signs of moderate efficacy for the addition of cetuximab, with better 
response rate $(27.7 \%, 95 \%$ CI 17.3 - 40.2 vs $18.2 \%, 95 \%$ CI $9.8-29.6)$, median PFS (5.09 months, 95\%CI 4.17 - 5.98 vs 4.21 months, 95\%CI $3.81-5.49$ ) and OS (11.99 months, 95\%CI 8.80 - 15.18 vs 9.26 months, 95\%CI 7.43 - 11.79) (46). A more recent, single arm study explored combining cetuximab to cisplatin and pemetrexed for 4-6 cycles, followed by maintenance with cetuximab and pemetrexed until progression or unacceptable toxicity. The study yielded slight improvements over past combinations in terms of ORR (38.5\%) and PFS (5.8 months) and similar OS (11.3 months) (47).

A further improvement was observed in the SWOG S0536 single-arm phase II study on 110 patients, in which both bevacizumab and cetuximab were added to carboplatin and paclitaxel for 6 cycles, with both antibodies kept for maintenance until progression. ORR was 56\%, PFS 7 months (95\% CI: 6-8 months) and median OS was 15 months (95\% CI: 11-21 months); toxicity profile was deemed acceptable, although there were 4 treatment-related deaths, 2 of which due to pulmonary hemorrhage, a well-known bevacizumab-related toxicity (48). This study was the basis for designing the ongoing phase III SWOG S0819 trial testing cetuximab plus carboplatin and paclitaxel, with or without bevacizumab (49).

Cetuximab was also studied as a single-agent in heavily pretreated NSCLC, obtaining a response rate of $4.5 \%$, in line with that of other antiblastics and EGFR inhibitors tested in the same setting (50).

\section{Phase III studies}

The pivotal phase III trial leading to FDA approval in NSCLC was FLEX (51). 1125 patients were randomized to receiving Cisplatin and Vinorelbin plus or minus Cetuximab (no placebo, open label); cetuximab was continued until progression or unacceptable toxicity. Importantly, patients were required to have IHCdemonstrated EGFR expression, but the cutoff chosen for positivity was very low (at least one postive tumor cell). The study showed a small but statistically significant OS improvement (1.2 months, 11.3 vs 10.1 months, HR=0.871, $\mathrm{p}=0.044$ ) at the price of worse toxicity profile (higher febrile neutropenia, rash, diarrhea and infusion-related reactions). The study spurred controversy in its aftermath. Despite the trial meeting its primary endpoint (OS), neither FDA nor EMA granted approval for NSCLC, given the marginal benefit and the use of a suboptimal comparator arm. Concerns grew as a subsequent trial (BMS099 (52)) in which cetuximab failed to demonstrate significant benefit when added to a possibly more effective chemotherapy. Chemotherapy-naive $(n=676)$ patients were randomized to receiving chemotherapy (carboplatin + a taxane at physician's choice) with vs without cetuximab. PFS, the primary endpoint, did not differ ( 4.4 vs 4.24 months, $\mathrm{HR}=0.902,95 \%$ CI $0.761-1.069, \mathrm{p}=0.24$ ); OS showed a trend favouring the cetuximab arm but the trial was not powerful enough to demonstrate such small OS improvement (9.7 vs 8.4 months, $\mathrm{HR}=0.89095 \%$ CI 0.754- 1.051; $\mathrm{p}=0.17$ ). Metanalyses pooling data from all four randomized trials described above (LUCAS, BMS100, BMS099 and FLEX) confirmed the modest but statistically significant advantage in OS of adding cetuximab to chemotherapy (53-55). Randomized studies are summarized in table 2.

There is some evidence supporting the use of cetuximab maintenance in monotherapy in patients free of disease after first line therapy with platinum- 
based CT. This trial (NEXT) was designed to test weekly vs bi-weekly cetuximab administration but recruitment was halted pematurely because of the EMA negative ruling on cetuximab (56). Results were nevertheless published and showed good OS of 12.6 months, comparable to other studies in the same setting, with no significant differences between the two adinistration schedules. Cetuximab was also tested in the second line setting after failure of platinumbased therapy, in combination with docetaxel or pemetrexed, but no significant improvement was observed (57).

\section{The search for predictive biomarkers}

Much research has attempted to identify genetic biomarkers predictive of response to anti-EGFR antibodies. These efforts have generated practicechanging results in colorectal cancer, but in the context of NSCLC things have been more difficult. Retrospective analyses of the FLEX and BMS099 trials showed no evidence that K-ras mutations or PTEN deletions mediate resistance to cetuximab (58-60). Also, the presence of an EGFR mutation is not predictive, as summarized in a Cochrane review (12). Instead, mounting evidence points to EGFR gene amplification and/or overexpression as a good predictive biomarker. In FLEX, cases with an elevated immunohistochemistry score (31\% of enrolled patients) had better survival when treated with the addition of cetuximab (median survival of 12.0 vs 9.6 months, HR 0.73, 95\% CI 0.58-0.93; p=0.011). A retrospective analysis of 2 phase II trials suggested better but marginally significant benefits from FISH-evaluated high EGFR copy number $(48,61)$. Preliminary results from the SWOG S0819 testing cetuximab with bevacizumab and chemotherapy confirmed this association (62). In apparent contrast with these findings, EGFR amplification showed no predictive power in FLEX (58). With a more careful look at the data, survival and response was possibly superior in FISH-positive patients treated with cetuximab (11.6 vs 9.9 months), but the number of samples analysed (25\% of the original 1125$)$ was certainly too small to confer sufficient power $(\mathrm{p}=0.44)$. Interestingly, in FLEX the percentage of patients FISH-positive is similar to those scored as high by IHC (37\% vs $31 \%)$, suggesting that the two tests may infact identify a largely overlappig population. This is confirmed by analysing data from The Cancer Genome Atlas, where it is clearly visible that EGFR amplification is associated with significant increase in EGFR mRNA expression (figure 1, data retrieved from cBioportal (63) on provisional lung adenocarcinoma and provisional squamous lung cancer on 14 october 2016)

\section{New combinations with biological agents}

Based on the laboratory finding that NSCLC with acquired resistance to erlotinib and gefitinib remain dependent on EGFR for growth $(64,65)$, several labs began testing combinations of alternative EGFR inhibitors for use after failure of TKI therapy. The combination of cetuximab and afatinib, a second generation TKI, proved effective on mouse models (66). This led to the design of a phase $1 \mathrm{~b}$ trial with a dose finding phase and two subsequent expansion phases exploring concurrent afatinib + cetuximab or afatinib +cetuximab initiated after failure of afatinib alone (67). In departure from previous schedules, cetuximab was administered as $500 \mathrm{mg} / \mathrm{m} 2$ every 2 weeks. 201 patients progressing to TKI for an EGFR-mutated NSCLC were enrolled, of which 126 were treated at the MTD of 
both drugs. ORR was 29\%, a good improvement from the 7-8\% observed in trials with afatinib or cetuximab alone on similar populations (68). Interestingly, cetuximab seems to also synergize with a novel allosteric EGFR inhibitor (EAI045) and the combination potently inhibits growth in mouse models of lung cancer driven by EGFR mutants resistant to all EGFR TKIs (69).

Other combinations with biologicals, such as with cilengitide (an integrin inhibitor)(70) or with cixutuxumab (IGF1R inhibitor) (71) did not give good results.

\section{Safety and tolerability}

The most characteristic toxicity associated with cetuximab is an acne-like rash, tha develops in up to $90 \%$ of patients and is dose-related $(72,73)$. It usually manifests within the first 2 weeks of therapy and is characterized by a maculopapular eruption localized to face and trunk, areas with high density of seborrheic glands. The rash is classified as G1-G2 in most cases, with a much smaller incidence of G3 or more events. However, since it is chronic and disfigurating, it is often a reason for treatment discontinuation. Also, there is a clear subjective bias for evaluating cetuximab rash severity, with oncologists systematically giving lower scores compared to dermatologists (74). The severity of rash is potentially increased when cetuximab is co-administered with radiotherapy (75), given the role of EGFR in the repair of skin lesions. However, the incidence of grade $\geq 3$ was similar in the phase 3 trials with chemo alone or chemoradiotherapy (10\% in FLEX, $9 \%$ in RTOG 0617) $(42,51)$. Combination of cetuximab with other EGFR inhibitors does not lead to increased severity of cutaneous toxicity (76). The rash may complicate with bacterial superinfections. Other skin toxicities are also common but rarely high grade with cetuximab, including xerosis, paronychia, hair growth abnormalities including alopecia and trichomegaly of the eyelashes/hypertrichosis of the face, and telangiectasias $(72,77)$. Topical or oral antibiotics (macrolides, clindamycin or tetracyclines), topical corticosteroids and vitamin $\mathrm{K}$ creams can be employed to control severity (72).

Other common toxicities are fatigue, fever, nausea, diarrhea, which are probably unrelated to dose or number of cycles administered (73). Less common are electrolyte imbalances, particularly hypomagnesemia (17), which may occur weeks or even months after cetuximab interruption and for which periodic monitoring during treatment and up to at least 8 weeks after treatment end is advised (73). In the two trials in which Quality of Life (QoL) measurements were reported $(51,52)$, no statistically significant differences were observed. Toxicity data as collected for the Cochrane metanaysis (55) is summarized in table 3.

\section{Expert opinion}

Cetuximab is currently not approved for NSCLC treatment in Europe nor in the USA. It remained on ASCO and NCCN guidelines for some years but it was removed from both documents in $2016(3,5)$. Despite statistically significant results from the registration studies, routine cetuximab use failed to gain consensus because of its high cost-benefit ratio: the price in both monetary and toxicity terms is cosidered too high for a marginal gain of 1.2 months in OS $(78,79)$. Thus, interest in this molecule has waned and remains confined to research setting. We think that the main reason for its failure lies in the inability 
to identify a clear predictive biomarker early during drug developement. The current emphasis on precision oncology based on genetic markers may carve a niche for cetuximab resurrection. Cetuximab-responsive NSCLC do exist out there, but they are likely to be a small and defined fraction of all NSCLC. Had such biomarker been identified before clinical developement, we might have seen a Herceptin-like story. In fact, we think that most efforts should be focused on consolidating the role of EGFR amplification as a predictive biomarker. Current evidence from the SWOG S0819 is still preliminary but deserves to be invested on.

A second possible niche is in the treatment of metastatic EGFR-mutated NSCLC in combination with new generation TKIs, hoping to slow down or temporarily revert the acquisition of genetic resistance. Recent data from preclinical and phase $1 \mathrm{~b}$ studies $(67,69)$ is promising. This strategy is currently being explored in randomized trials, on TKI-naïve patients (NCT02438722, NCT02716311) and on patients with acquired resistance (NCT00716456).

Lastly, in the context of locally advanced NSCLC, further research should investigate its role as adjunct to radiotherapy in patients unfit to undergo chemoradiation. This approach has gained some following in the context of Head and Neck cancer (80), but in NSCLC the evidence in favour of this approach is so far represented only by small nonrandomized studies $(38,39)$. The impact on quality of life, if demonstrated noninferior to chemoradiation, might be high.

\section{Conclusion}

Cetuximab demonstrated improved efficacy over standard therapy in both locally advanced and metastatic NSCLC, but the absolute survival gain in unselected populations is very small and so far deemed unjustifiable in light of the chronic toxicity. Further research is required to identify highly selected patient subsets where cetuximab may still have a beneficial impact

\section{Article highlights}

- Cetuximab provides statistically significant but clinically marginal OS gain in unselected NSCLC

- It is currently not a viable therapeutic option in routine practice

- EGFR amplification is a likely predictive biomarker

- Combining cetuximab to EGFR TKIs may be effective in cases of primary or acquired TKI resistance

- Its role as adjunct to radiotherapy in stage IIIA patients unfit for chemoradiation should be explored

\section{References}

1. Surveillance, Epidemiology, and End Results (SEER) Program. 2016.

2. - ACS. Non-small cell lung cancer survival rates, by stage.

3. Masters GA, Graham HF, Temin S, Jr SB, Trent D, Azzoli CG, et al. Systemic Therapy for Stage IV Non - Small-Cell Lung Cancer : American Society of Clinical Oncology Clinical Practice Guideline Update. J Clin Oncol. 
2016;33(30).

4. Eberhardt WEE. Concurrent Chemoradiotherapy in Stage III Non-SmallCell Lung Cancer: What Is the Best Regimen? J Clin Oncol . 2015 Jan 5;

5. National Comprehensive Cancer Network. NCCN Clinical Practice Guidelines in Oncology (NCCN Guidelines $囚)$ non-small cell lung cancer. 2016.

6. Garon EB, Ciuleanu T-E, Arrieta O, Prabhash K, Syrigos KN, Goksel T, et al. Ramucirumab plus docetaxel versus placebo plus docetaxel for second-line treatment of stage IV non-small-cell lung cancer after disease progression on platinum-based therapy (REVEL): a multicentre, double-blind, randomised phase 3 trial. Lancet. Elsevier; 2016 Oct 11;384(9944):66573.

7. Sandler A, Gray R, Perry MC, Brahmer J, Schiller JH, Dowlati A, et al. Paclitaxel-Carboplatin Alone or with Bevacizumab for Non-Small-Cell Lung Cancer. N Engl J Med. Massachusetts Medical Society; 2006 Dec 14;355(24):2542-50.

8. Shaw AT, Ou S-HI, Bang Y-J, Camidge DR, Solomon BJ, Salgia R, et al. Crizotinib in ROS1-Rearranged Non-Small-Cell Lung Cancer. N Engl J Med. Massachusetts Medical Society; 2014 Sep 27;371(21):1963-71.

9. Solomon BJ, Mok T, Kim D-W, Wu Y-L, Nakagawa K, Mekhail T, et al. FirstLine Crizotinib versus Chemotherapy in ALK-Positive Lung Cancer. N Engl J Med. Massachusetts Medical Society; 2014 Dec 3;371(23):2167-77.

10. Shaw AT, Kim D-W, Mehra R, Tan DSW, Felip E, Chow LQM, et al. Ceritinib in ALK-Rearranged Non-Small-Cell Lung Cancer. N Engl J Med.

Massachusetts Medical Society; 2014 Mar 26;370(13):1189-97.

11. Han B, Tjulandin S, Hagiwara K, Normanno N, Wulandari L, Konstantin Konstantinovich L, et al. DETERMINING THE PREVALENCE OF EGFR MUTATIONS IN ASIAN AND RUSSIAN PATIENTS (PTS) WITH ADVANCED NON-SMALL-CELL LUNG CANCER (ANSCLC) OF ADENOCARCINOMA (ADC) AND NON-ADC HISTOLOGY: IGNITE STUDY. Ann Oncol. 2015 Apr 1;26(suppl 1):i29-30.

12. Greenhalgh J, Dwan K, Boland A, Bates V, Vecchio F, Dundar Y, et al. Firstline treatment of advanced epidermal growth factor receptor ( EGFR ) mutation positive non-squamous non-small cell lung cancer ( Review ) SUMMARY OF FINDINGS FOR THE MAIN COMPARISON. 2016;(5).

13. Fehrenbacher L, Spira A, Ballinger M, Kowanetz M, Vansteenkiste J, Mazieres J, et al. Atezolizumab versus docetaxel for patients with previously treated non-small-cell lung cancer ( POPLAR ): a multicentre , open-label , phase 2 randomised controlled trial. Lancet. Elsevier Ltd; 2016;387(10030):1837-46.

14. Reck M, Rodríguez-Abreu D, Robinson AG, Hui R, Csőszi T, Fülöp A, et al. Pembrolizumab versus Chemotherapy for PD-L1-Positive Non-Small-Cell Lung Cancer. N Engl J Med. Massachusetts Medical Society; 2016 Oct 8;

15. Borghaei H, Paz-Ares L, Horn L, Spigel DR, Steins M, Ready NE, et al. Nivolumab versus Docetaxel in Advanced Nonsquamous Non-Small-Cell Lung Cancer. N Engl J Med. Massachusetts Medical Society; 2015 Sep 27;373(17):1627-39.

16. Schiller JH, von Pawel J, Schütt P, Ansari RH, Thomas M, Saleh M, et al. Pemetrexed with or without Matuzumab as Second-Line Treatment for 
Patients with Stage IIIB/IV Non-small Cell Lung Cancer. J Thorac Oncol. 2010 Dec;5(12):1977-85.

17. Schrag D, Chung KY, Flombaum C, Saltz L. Cetuximab Therapy and Symptomatic Hypomagnesemia. J Natl Cancer Inst . 2005 Aug 17;97 (16 ):1221-4.

18. Thatcher N, Hirsch FR, Luft A V, Szczesna A, Ciuleanu TE, Dediu M, et al. Necitumumab plus gemcitabine and cisplatin versus gemcitabine and cisplatin alone as fi rst-line therapy in patients with stage IV squamous non-small-cell lung cancer ( SQUIRE ): an open-label, randomised , controlled phase 3 trial. 2015;16(July):763-74.

19. Veale D, Ashcroft T, Marsh C, Gibson GJ HA. Epidermal growth factor receptors in non-small cell lung cancer. Br J Cancer. 1987;55(5):513-6.

20. Kawamoto T, Sato JD, Le A, Polikoff J, Sato GH, Mendelsohn J. Growth stimulation of A431 cells by epidermal growth factor: identification of high-affinity receptors for epidermal growth factor by an anti-receptor monoclonal antibody. Proc Natl Acad Sci . 1983 Mar 1;80 (5 ):1337-41.

21. Masui H, Kawamoto T, Sato JD, Wolf B, Sato G, Mendelsohn J. Growth Inhibition of Human Tumor Cells in Athymic Mice by Anti-Epidermal Growth Factor Receptor Monoclonal Antibodies. Cancer Res. 1984 Mar 1;44(3):1002 LP - 1007.

22. Masui H, Moroyama T, Mendelsohn J. Mechanism of Antitumor Activity in Mice for Anti-Epidermal Growth Factor Receptor Monoclonal Antibodies with Different Isotypes. Cancer Res. 1986 Nov 1;46(11):5592 LP - 5598.

23. Fan Z, Masui H, Altas I, Mendelsohn J. Blockade of Epidermal Growth Factor Receptor Function by Bivalent and Monovalent Fragments of 225 Anti-Epidermal Growth Factor Receptor Monoclonal Antibodies. Cancer Res. 1993 Sep 1;53(18):4322 LP - 4328.

24. Naramura, , Gillies SD, Mendelsohn J, Reisfeld RA MB. Therapeutic potential of chimeric and murine anti-(epidermal growth factor receptor) antibodies in a metastasis model for human melanoma. Cancer Immunol Immunother. 1993;37(5):343-9.

25. Baselga J, Norton L, Masui H, Pandiella A, Coplan K, Miller WH, et al. Antitumor Effects of Doxorubicin in Combination With Anti-epidermal Growth Factor Receptor Monoclonal Antibodies. J Natl Cancer Inst . 1993 Aug 1;85 (16):1327-33.

26. Goldstein NI, Prewett M, Zuklys K, Rockwell P, Mendelsohn J. Biological efficacy of a chimeric antibody to the epidermal growth factor receptor in a human tumor xenograft model. Clin Cancer Res. 1995 Nov 1;1(11):1311 LP - 1318.

27. Sunada H, Magun BE, Mendelsohn J, MacLeod CL. Monoclonal antibody against epidermal growth factor receptor is internalized without stimulating receptor phosphorylation. Proc Natl Acad Sci . 1986 Jun 1;83 (11):3825-9.

28. Wang M, Morsbach F, Sander D, Gheorghiu L, Nanda A, Benes C, et al. EGF Receptor Inhibition Radiosensitizes NSCLC Cells by Inducing Senescence in Cells Sustaining DNA Double-Strand Breaks. Cancer Res. 2011 Sep 29;71(19):6261 LP - 6269.

29. Pozzi C, Cuomo A, Spadoni I, Magni E, Silvola A, Conte A, et al. The EGFRspecific antibody cetuximab combined with chemotherapy triggers 
immunogenic cell death. Nat Med. Nature Publishing Group, a division of Macmillan Publishers Limited. All Rights Reserved.; 2016 Jun;22(6):62431.

30. E. H. Rubin, J. Doroshow, M. Hidalgo, M. Wojtowicz, L. Leong, R. Donehower SB and DM. A study to assess the pharmacokinetics (PK) of a single infusion of cetuximab (IMC-C225). J Clin Oncol. 2004;22(14S):3084.

31. Baselga J, Pfister D, Cooper MR, Cohen R, Burtness B, Bos M, et al. Phase I Studies of Anti-Epidermal Growth Factor Receptor Chimeric Antibody C225 Alone and in Combination With Cisplatin. J Clin Oncol . 2000 Feb 14;18 (4):904.

32. Robert F, Ezekiel MP, Spencer SA, Meredith RF, Bonner JA, Khazaeli MB, et al. Phase I Study of Anti-Epidermal Growth Factor Receptor Antibody Cetuximab in Combination With Radiation Therapy in Patients With Advanced Head and Neck Cancer. J Clin Oncol . 2001 Jul 1;19 (13 ):323443.

33. Rosell R, Robinet G, Szczesna A, Ramlau R, Constenla M, Mennecier B, et al. Randomized phase II study of cetuximab plus cisplatin / vinorelbine compared with cisplatin / vinorelbine alone as first-line therapy in EGFRexpressing advanced non-small-cell lung cancer. 2008;(October 2007):362-9.

34. Wong S. Cetuximab : An Epidermal Growth Factor Receptor Monoclonal Antibody for the Treatment of Colorectal Cancer. Clin Ther. 2005;27(6):684-94.

35. Govindan R, Bogart J, Stinchcombe T, Wang X, Hodgson L, Kratzke R, et al. Randomized Phase II Study of Pemetrexed, Carboplatin , and Thoracic Radiation With or Without Cetuximab in Patients With Locally Advanced Unresectable Non - Small-Cell Lung Cancer : Cancer and Leukemia Group B Trial 30407. J Clin Oncol. 2011;1-7.

36. Jr GRB, Paulus R, Curran WJ, Robert F, Fossella F, Werner-wasik M, et al. Phase II Study of Cetuximab in Combination With Chemoradiation in Patients With Stage IIIA / B Non - Small-Cell Lung Cancer : RTOG 0324. J Clin Oncol. 2016;1-7.

37. Hallqvist A, Wagenius G, Rylander H, Brodin O, Holmberg E, Lödén B, et al. Concurrent cetuximab and radiotherapy after docetaxel-cisplatin induction chemotherapy in stage III NSCLC: Satellite-A phase II study from the Swedish Lung Cancer Study Group. Lung Cancer. 2011 Feb;71(2):166-72.

38. Jensen AD, Münter MW, Bischoff HG, Haselmann R, Haberkorn U, Huber $\mathrm{PE}$, et al. Combined treatment of nonsmall cell lung cancer NSCLC stage III with intensity-modulated RT radiotherapy and cetuximab. Cancer. Wiley Subscription Services, Inc., A Wiley Company; 2011;117(13):2986-94.

39. Jatoi A, Schild SE, Foster N, Henning GT, Dornfeld KJ, Flynn PJ, et al. A phase II study of cetuximab and radiation in elderly and / or poor performance status patients with locally advanced non-small-cell lung cancer ( N0422 ). Ann Oncol. 2010;(June):2040-4.

40. Heuvel MM Van Den, Uyterlinde W, Vincent AD, Jong J De, Aerts J, Koppe F, et al. Additional weekly Cetuximab to concurrent chemoradiotherapy in locally advanced non-small cell lung carcinoma : Efficacy and safety outcomes of a randomized, multi-center phase II study investigating. 
Radiother Oncol. Elsevier Ireland Ltd; 2014;110(1):126-31.

41. Anne-Marie C. Dingemans, MD, PhD, , Gerben Bootsma, MD, PhD, $\dagger$ Angela van Baardwijk, MD, PhD, $\neq$ Bart Reymen, MD, $\neq$ Rinus Wanders, MD, $\neq$ Boudewijn Brans, MD, PhD,§ Marco Das, MD, PhD, || Monique Hochstenbag, $\mathrm{MD}, \mathrm{PhD},{ }^{*}$ Arne van Belle, MD,* Ruud Houben, MSc, $\neq$ Phil P. A Phase I Study of Concurrent Individualized, Isotoxic Accelerated Radiotherapy and Cisplatin - Vinorelbine - Cetuximab in Patients With Stage III NonSmall-Cell Lung Cancer. J Thorac Oncol. International Association for the Study of Lung Cancer; 2014;9(5):710-6.

42. Bradley JD, Paulus R, Komaki R, Masters G, Blumenschein G, Schild S, et al. Standard-dose versus high-dose conformal radiotherapy with concurrent and consolidation carboplatin plus paclitaxel with or without cetuximab for patients with stage IIIA or IIIB non-small-cell lung cancer ( RTOG 0617 ): a randomised , two-by-two factoria. Lancet Oncol. 2015;16:187-99.

43. Nieder C, Pawinski A, Dalhaug A, Andratschke N. A review of clinical trials of cetuximab combined with radiotherapy for non-small cell lung cancer. 2012;1-7.

44. Thienelt CD, Jr PAB, Hanna N, Rosenberg A, Needle MN, Long ME, et al. Multicenter Phase I / II Study of Cetuximab With Paclitaxel and Carboplatin in Untreated Patients With Stage IV Non - Small-Cell Lung Cancer. 2016;23(34).

45. Robert F, Blumenschein G, Herbst RS, Fossella F V, Tseng J. J OURNAL OF C LINICAL O NCOLOGY Phase I / IIa Study of Cetuximab With Gemcitabine Plus Carboplatin in Patients With Chemotherapy-Nal "ve Advanced Non Small-Cell Lung Cancer. 2016;23(36):9089-96.

46. Butts CA, Bodkin D, Middleman EL, Englund CW, Ellison D, Alam Y, et al. Randomized Phase II Study of Gemcitabine Plus Cisplatin or Carboplatin, With or Without Cetuximab , As First-Line Therapy for Patients With Advanced or Metastatic Non - Small-Cell Lung Cancer. J Clin Oncol. 2007;25(36).

47. Schmid-bindert G, Gebbia V, Mayer F, Arriola E, Márquez-medina D, Syrigos K, et al. Phase II study of pemetrexed and cisplatin plus cetuximab followed by pemetrexed and cetuximab maintenance therapy in patients with advanced nonsquamous non-small cell lung cancer. Lung Cancer. Elsevier Ireland Ltd; 2013;81(3):428-34.

48. Kim ES, Moon J, Herbst RS, Redman MW, Kelly K, John V. Bevacizumab Followed by Cetuximab and Bevacizumab in Advanced Nonsquamous Non - Small-Cell Lung Cancer. J Thorac Oncol. International Association for the Study of Lung Cancer; 2013;8(12):1519-28.

49. Redman MW, Crowley JJ, Herbst RS, Hirsch FR, Gandara DR. Design of a Phase III Clinical Trial with Prospective Biomarker Validation: SWOG S0819. Clin Cancer Res. 2012 Jul 30;18(15):4004 LP - 4012.

50. Hanna N, Lilenbaum R, Ansari R, Lynch T, Govindan R, Jänne PA, et al. Phase II Trial of Cetuximab in Patients With Previously Treated NonSmall-Cell Lung Cancer. J Clin Oncol . 2006 Nov 20;24 (33 ):5253-8.

51. Pirker R, Pereira JR, Szczesna A, Pawel J Von, Krzakowski M, Ramlau R, et al. Cetuximab plus chemotherapy in patients with advanced non-small-cell lung cancer ( FLEX): an open-label randomised phase III trial. Lancet. Elsevier Ltd; 2009;373(9674):1525-31. 
52. Lynch TJ, Patel T, Dreisbach L, Mccleod M, Heim WJ, Hermann RC, et al. Cetuximab and First-Line Taxane / Carboplatin Chemotherapy in Advanced Non - Small-Cell Lung Cancer : Results of the Randomized Multicenter Phase III Trial BMS099. J Clin Oncol. 2010;28(6):911-7.

53. Pujol J, Pirker R, Lynch TJ, Butts CA, Rosell R, Shepherd FA, et al. Metaanalysis of individual patient data from randomized trials of chemotherapy plus cetuximab as first-line treatment for advanced nonsmall cell lung cancer. Lung Cancer. Elsevier Ireland Ltd; 2014;83(2):2118.

54. Ibrahim EM, Abouelkhair KM, Al-Masri OA, Chaudry NC, Kazkaz GA. Cetuximab-based Therapy is Effective in Chemotherapy-nar Patients with Advanced and Metastatic Non-small-cell Lung Cancer : A Meta-analysis of Randomized Controlled Trials. Lung. 2011;189:193-8.

55. Yang Z-Y, Liu L, Mao C, Wu X-Y, Huang Y-F, Hu X-F, et al. Chemotherapy with cetuximab versus chemotherapy alone for chemotherapy-naive advanced non-small cell lung cancer. Cochrane Database Syst Rev. John Wiley \& Sons, Ltd; 2014;(11).

56. Heigener DF, Pereira JR, Felip E, Mazal J, Manzyuk L, Tan EH, et al. Weekly and every 2 weeks cetuximab maintenance therapy after platinum-based chemotherapy plus cetuximab as first-line treatment for non-small cell lung cancer : randomized non-comparative phase IIIb NEXT trial. Targ Oncol. 2015;255-65.

57. Kim ES, Neubauer M, Cohn A, Schwartzberg L, Garbo L, Caton J, et al. Docetaxel or pemetrexed with or without cetuximab in recurrent or progressive non-small-cell lung cancer after platinum-based therapy : a phase 3 , open-label , randomised trial. Lancet Oncol. Elsevier Ltd; 2013;14(13):1326-36.

58. O'Byrne KJ, Gatzemeier U, Bondarenko I, Barrios C, Eschbach C, Martens UM, et al. Molecular biomarkers in non-small-cell lung cancer: a retrospective analysis of data from the phase 3 FLEX study. Lancet Oncol. 2011 Aug;12(8):795-805.

59. Khambata-Ford S, Harbison CT, Hart LL, Awad M, Xu L-A, Horak CE, et al. Analysis of Potential Predictive Markers of Cetuximab Benefit in BMS099, a Phase III Study of Cetuximab and First-Line Taxane/Carboplatin in Advanced Non-Small-Cell Lung Cancer. J Clin Oncol . 2010 Feb 20;28 (6 ):918-27.

60. Roberts PJ, Stinchcombe TE, Der CJ, Socinski MA. Personalized Medicine in Non - Small-Cell Lung Cancer : Is KRAS a Useful Marker in Selecting Patients for Epidermal Growth Factor Receptor - Targeted Therapy? J Clin Oncol. 2010;28(31):4769-77.

61. Herbst RS, Kelly K, Chansky K, Mack PC, Franklin WA, Hirsch FR, et al. Phase II Selection Design Trial of Concurrent Chemotherapy and Cetuximab Versus Chemotherapy Followed by Cetuximab in AdvancedStage Non - Small-Cell Lung Cancer : Southwest Oncology Group Study S0342. J Clin Oncol. 2010;28(31):4747-54.

62. R. Herbst, M. Redman, E.S. Kim, T.J. Semrad, L. Bazhenova, G. Masters, K. Oettel, P. Guaglianone, C. Reynolds, A. Karnad, S.M. Arnold, M. VarellaGarcia, J. Moon, P.C. Mack, C.D. Blanke, F.R. Hirsch DRG. A randomized, phase III study comparing carboplatin/paclitaxel or 
carboplatin/paclitaxel/bevacizumab with or without concurrent cetuximab in patients with advanced non-small cell lung cancer (NSCLC): SWOG S0819. In: 16th World Conference on Lung Cancer. 2015. p. PLEN04.01.

63. Gao J, Aksoy BA, Dogrusoz U, Dresdner G, Gross B, Sumer SO, et al. Integrative Analysis of Complex Cancer Genomics and Clinical Profiles Using the cBioPortal. Sci Signal. 2013 Apr 2;6(269):pl1 LP - pl1.

64. Kobayashi S, Boggon TJ, Dayaram T, Jänne PA, Kocher O, Meyerson M, et al. EGFR Mutation and Resistance of Non-Small-Cell Lung Cancer to Gefitinib. N Engl J Med. Massachusetts Medical Society; 2005 Feb 24;352(8):786-92.

65. Pao W, Miller VA, Politi KA, Riely GJ, Somwar R, Zakowski MF, et al. Acquired Resistance of Lung Adenocarcinomas to Gefitinib or Erlotinib Is Associated with a Second Mutation in the EGFR Kinase Domain. 2005;2(3).

66. Regales L, Gong Y, Shen R, Stanchina E De, Vivanco I, Goel A, et al. Dual targeting of EGFR can overcome a major drug resistance mutation in mouse models of EGFR mutant lung cancer. J Clin Invest. 2009;119(10):3000-10.

67. Janjigian YY, Smit EF, Groen HJM, Horn L, Gettinger S, Camidge DR, et al. Dual Inhibition of EGFR with Afatinib and Cetuximab in Kinase Inhibitor Resistant EGFR -Mutant Lung Cancer with and without T790M Mutations. Cancer Discov. 2014;4(9):1036-45.

68. Neal JW, Heist RS, Fidias P, Temel JS, Huberman M, Marcoux JP, et al. Cetuximab Monotherapy in Patients with Advanced Non-small Cell Lung Cancer After Prior Epidermal Growth Factor Receptor Tyrosine Kinase Inhibitor Therapy. J Thorac Oncol. 2010 Nov;5(11):1855-8.

69. Jia Y, Yun C, Park E, Ercan D, Manuia M, Juarez J, et al. resistance with mutant-selective allosteric inhibitors. Nature. Nature Publishing Group; 2016;534(7605):129-32.

70. Vansteenkiste J, Barlesi F, Waller CF, Bennouna J, Gridelli C, Goekkurt E, et al. Cilengitide combined with cetuximab and platinum-based chemotherapy as fi rst-line treatment patients : results of an open-label , randomized, controlled phase II study ( CERTO ). 2015;(May):1734-40.

71. Hanna NH, Dahlberg SE, Kolesar JM, Aggarwal C. Three-Arm , Randomized, Phase 2 Study of Carboplatin and Paclitaxel in Combination With Cetuximab , Cixutumumab , or Both for Advanced Non - Small Cell Lung Cancer ( NSCLC) Patients Who Will Not Receive Bevacizumab-Based Therapy : An Eastern Cooperative Oncology Group ( ECOG ) Study ( E4508 ). 2015;2253-61.

72. Pinto C, Barone CA, Girolomoni G. Management of Skin Reactions During Cetuximab Treatment in Association With Chemotherapy or Radiotherapy Update of the Italian Expert Recommendations. 2016;39(4):407-15.

73. Changes------- M. See full prescribing information for complete boxed warning. $\bullet$. 2004;1-31.

74. Duffour J, Thézenas S, Dereure O, Garcin A, Caron J, Samalin E, et al. Interobserver agreement between dermatologists and oncologists in assessing dermatological toxicities in patients with metastatic colorectal cancer treated by cetuximab-based chemotherapies: A pilot comparative study. Eur J Cancer. 2010 Dec;46(18):3169-74.

75. Budach W, Bölke E, Homey B. Severe Cutaneous Reaction during Radiation 
Therapy with Concurrent Cetuximab. N Engl J Med. Massachusetts Medical Society; 2007 Aug 2;357(5):514-5.

76. Guarino MJ, Schneider CJ, Hosford MA, Brahmer JR, Rudin CM, Finckenstein FG, et al. Dual Inhibition of the Epidermal Growth Factor Receptor Pathway with Cetuximab and Erlotinib: A Phase I Study in Patients with Advanced Solid Malignancies. Oncol . 2009 Feb 1;14 (2 ):119-24.

77. Lynch TJ, Kim ES, Eaby B, Garey J, West DP, Lacouture ME. Epidermal Growth Factor Receptor Inhibitor-Associated Cutaneous Toxicities: An Evolving Paradigm in Clinical Management. Oncol . 2007 May 1;12 (5 ):610-21.

78. Fojo T, Grady C. How Much Is Life Worth: Cetuximab, Non-Small Cell Lung Cancer, and the $\$ 440$ Billion Question. J Natl Cancer Inst . 2009 Aug 5;101 (15):1044-8.

79. Gyawali B, Prasad V. Same Data; Different Interpretations. J Clin Oncol . 2016 Aug 29;

80. Bonner JA, Harari PM, Giralt J, Azarnia N, Shin DM, Cohen RB, et al. Radiotherapy plus Cetuximab for Squamous-Cell Carcinoma of the Head and Neck. N Engl J Med. Massachusetts Medical Society; 2006 Feb 9;354(6):567-78. 
Table 1: Trials combining cetuximab with (chemo)radiation

\begin{tabular}{|c|c|c|c|c|c|c|c|c|}
\hline & Year & $\begin{array}{l}\text { study } \\
\text { type }\end{array}$ & n Pts & $\begin{array}{l}\text { Patient } \\
\text { stage }\end{array}$ & $\begin{array}{l}\text { Chemotherapy } \\
\text { regimen }\end{array}$ & $\begin{array}{l}\text { RT } \\
\text { (Gy) }\end{array}$ & $\begin{array}{l}\text { OS } \\
\text { (mon } \\
\text { ths) }\end{array}$ & $\begin{array}{l}2- \\
\text { yr } \\
\text { S } \\
O \\
\text { S }\end{array}$ \\
\hline $\begin{array}{l}\text { No422, } \\
\text { Jatoi et al }\end{array}$ & 2010 & $\begin{array}{l}\text { phase } 2, \\
\text { single } \\
\text { arm }\end{array}$ & 58 & $\begin{array}{l}\text { IIIA } 59 \%, \\
\text { IIIB } 49 \%\end{array}$ & $\begin{array}{l}\text { Concurrent } \\
\text { Cetuximab }\end{array}$ & 60 & 15.1 & $\begin{array}{l}22 \\
\%\end{array}$ \\
\hline $\begin{array}{l}\text { NEAR, } \\
\text { Jensen et } \\
\text { al }\end{array}$ & 2011 & $\begin{array}{l}\text { phase 2, } \\
\text { single } \\
\text { arm }\end{array}$ & 30 & $\begin{array}{l}\text { II } 7 \% \text {, } \\
\text { IIIA } 57 \% \text {, } \\
\text { IIIB } 37 \%\end{array}$ & $\begin{array}{l}\text { Concurrent } \\
\text { Cetuximab } \\
\text { followed by } \\
\text { maintenance } \\
\text { Cetuximab }\end{array}$ & 66 & 19.5 & $\begin{array}{l}35 \\
\%\end{array}$ \\
\hline $\begin{array}{l}\text { SATELLIT } \\
\text { E, } \\
\text { Hallqvist et } \\
\text { al }\end{array}$ & 2011 & $\begin{array}{l}\text { phase II, } \\
\text { single } \\
\text { arm }\end{array}$ & 71 & $\begin{array}{l}\text { IIIA 37\%, } \\
\text { IIIB 63\% }\end{array}$ & $\begin{array}{l}\text { Induction } \\
\text { Docetaxel and } \\
\text { CDDP followed by } \\
\text { concurrent } \\
\text { Cetuximab }\end{array}$ & 68 & 17 & $\begin{array}{l}37 \\
\%\end{array}$ \\
\hline $\begin{array}{l}\text { RTOG } \\
\text { o324, } \\
\text { Blumensch } \\
\text { ein et al }\end{array}$ & 2011 & $\begin{array}{l}\text { phase II, } \\
\text { single } \\
\text { arm }\end{array}$ & 87 & $\begin{array}{l}\text { IIIA } 46 \%, \\
\text { IIIB } 54 \%\end{array}$ & $\begin{array}{l}\text { Concurrent } \\
\text { CBDCA, } \\
\text { Paclitaxel and } \\
\text { Cetuximab } \\
\text { followed by } \\
\text { Consolidation } \\
\text { CBDCA and } \\
\text { Paclitaxel }\end{array}$ & 65 & 22.7 & $\begin{array}{l}49 \\
\%\end{array}$ \\
\hline \multirow[t]{2}{*}{$\begin{array}{l}\text { CALGB } \\
\text { 30407, } \\
\text { Govindan } \\
\text { et al }\end{array}$} & \multirow[t]{2}{*}{2011} & \multirow[t]{2}{*}{$\begin{array}{l}\text { phase II, } \\
\text { randomi } \\
\text { zed }\end{array}$} & \multirow[t]{2}{*}{\begin{tabular}{|l|}
101 \\
\end{tabular}} & \multirow[t]{2}{*}{$\begin{array}{l}\text { IIIA } 55 \% \text {, } \\
\text { IIIB } 42 \%\end{array}$} & $\begin{array}{l}\text { Concurrent } \\
\text { CBDCA and } \\
\text { Pemetrexed } \\
\text { followed by } \\
\text { consolidation } \\
\text { Pemetrexed }\end{array}$ & \multirow[t]{2}{*}{70} & 21.2 & \\
\hline & & & & & $\begin{array}{l}\text { Concurrent } \\
\text { CBDCA and } \\
\text { Pemetrexed + } \\
\text { Cetuximab } \\
\text { followed by } \\
\text { consolidation } \\
\text { Pemetrexed }\end{array}$ & & 25.2 & \\
\hline \multirow[t]{2}{*}{$\begin{array}{l}\text { van den } \\
\text { Heuvel et } \\
\text { al }\end{array}$} & 2014 & $\begin{array}{l}\text { phase II, } \\
\text { randomi } \\
\text { zed }\end{array}$ & 102 & $\begin{array}{l}\text { II } 8 \% \text {, } \\
\text { IIIA } 51 \% \text {, } \\
\text { IIIB } 41 \%\end{array}$ & $\begin{array}{l}\text { Concurrent } \\
\text { Cisplatin }\end{array}$ & 66 & $\begin{array}{l}\text { n.a. } \\
\text { (HR } \\
=1)\end{array}$ & $\begin{array}{l}58 \\
\%\end{array}$ \\
\hline & & & & & $\begin{array}{l}\text { Concurrent } \\
\text { Cisplatin + } \\
\text { Cetuximab }\end{array}$ & & & $\begin{array}{l}62 \\
\%\end{array}$ \\
\hline \multirow[t]{2}{*}{$\begin{array}{l}\text { RTOG } \\
\text { o617, } \\
\text { Bradley et } \\
\text { al }\end{array}$} & 2015 & $\begin{array}{l}\text { phase } \\
\text { III, } \\
\text { randomi } \\
\text { zed }\end{array}$ & 465 & $\begin{array}{l}\text { IIIA 65\%, } \\
\text { IIIB 35\% }\end{array}$ & $\begin{array}{l}\text { Concurrent and } \\
\text { consolidation } \\
\text { CBDCA and } \\
\text { Paclitaxel }\end{array}$ & \multirow[t]{2}{*}{$\begin{array}{l}60 \text { or } \\
74\end{array}$} & $\begin{array}{l}24 \\
(19.8 \\
- \\
28.6)\end{array}$ & $\begin{array}{l}50 \\
.1 \\
0 \\
\%\end{array}$ \\
\hline & & & & & $\begin{array}{l}\text { Concurrent and } \\
\text { consolidation } \\
\text { CBDCA and } \\
\text { Paclitaxel }+ \\
\text { cetuximab }\end{array}$ & & $\begin{array}{l}25 \\
(20.2 \\
- \\
3056 \\
)\end{array}$ & $\begin{array}{l}52 \\
\cdot 3 \\
0 \\
\%\end{array}$ \\
\hline
\end{tabular}

URL: http://mc.manuscriptcentral.com/eobt Email: David.Grech@informa.com 
Table 2. Randomized trials in stage IIIB-IV NSCLC

\begin{tabular}{|c|c|c|c|c|c|c|c|}
\hline Reference & Year & $\begin{array}{l}\text { study } \\
\text { type }\end{array}$ & $\begin{array}{l}\text { Patient } \\
\text { number }\end{array}$ & Therapy regimen & $\begin{array}{l}\text { OS } \\
\text { months } \\
(95 \% \\
\mathrm{Cl}) \\
\end{array}$ & $\begin{array}{l}\text { PFS } \\
\text { months } \\
(95 \% \\
\mathrm{Cl})\end{array}$ & ORR \\
\hline \multirow[t]{2}{*}{$\begin{array}{l}\text { FLEX, } \\
\text { Pirker et } \\
\text { al }\end{array}$} & \multirow[t]{2}{*}{2009} & \multirow[t]{2}{*}{$\begin{array}{l}\text { phase } \\
3\end{array}$} & \multirow[t]{2}{*}{1125} & Cetuximab+cisplatin+vinorelbine & $\begin{array}{l}10.5 \\
(9.2- \\
12.0) \\
\end{array}$ & $\begin{array}{l}4.8 \\
(4.2- \\
5.3) \\
\end{array}$ & $36 \%$ \\
\hline & & & & cisplatin+vinorelbine & $\begin{array}{l}9.1 \\
(8.2- \\
10.1) \\
\end{array}$ & $\begin{array}{l}4.8 \\
(4.4- \\
5.3) \\
\end{array}$ & $29 \%$ \\
\hline \multirow[t]{2}{*}{ BMS 099, } & \multirow[t]{2}{*}{2010} & \multirow[t]{2}{*}{$\begin{array}{l}\text { phase } \\
3\end{array}$} & \multirow[t]{2}{*}{676} & Cetuximab+carboplatin+taxane & $\begin{array}{l}9.69 \\
(8.28- \\
11.5)\end{array}$ & $\begin{array}{l}4.4 \\
(4.11- \\
5.06) \\
\end{array}$ & $25.70 \%$ \\
\hline & & & & carboplatin+taxane & $\begin{array}{l}8.38 \\
(7.33- \\
9.62)\end{array}$ & $\begin{array}{l}4.24 \\
(3.94- \\
4.63) \\
\end{array}$ & $17.20 \%$ \\
\hline \multirow[t]{2}{*}{$\begin{array}{l}\text { BMS 100, } \\
\text { Butts et al }\end{array}$} & \multirow[t]{2}{*}{2007} & \multirow[t]{2}{*}{$\begin{array}{l}\text { phase } \\
2\end{array}$} & \multirow[t]{2}{*}{130} & Cetuximab+platinum+gemcitabine & $\begin{array}{l}11.99 \\
(8.8- \\
15.18)\end{array}$ & $\begin{array}{l}5.09 \\
(4.17- \\
5.98) \\
\end{array}$ & $27.70 \%$ \\
\hline & & & & platinum+gemcitabine & $\begin{array}{l}9.26 \\
(7.43- \\
11.79)\end{array}$ & $\begin{array}{l}4.21 \\
(3.81- \\
5.49) \\
\end{array}$ & $18.20 \%$ \\
\hline \multirow{2}{*}{$\begin{array}{l}\text { Lung } \\
\text { Cancer } \\
\text { Cetuximab } \\
\text { Study, } \\
\text { Rosell et } \\
\text { al }\end{array}$} & \multirow[t]{2}{*}{2008} & \multirow[t]{2}{*}{$\begin{array}{l}\text { phase } \\
2\end{array}$} & \multirow[t]{2}{*}{86} & Cetuximab+cisplatin+vinorelbine & $\begin{array}{l}8.3 \\
(6.1- \\
9.9) \\
\end{array}$ & $\begin{array}{l}5(4.5- \\
5.8)\end{array}$ & $35 \%$ \\
\hline & & & & cisplatin+vinorelbine & $\begin{array}{l}7.3 \\
(5.6- \\
9.5) \\
\end{array}$ & $\begin{array}{l}4.6 \\
(2.5- \\
6.0) \\
\end{array}$ & $28 \%$ \\
\hline
\end{tabular}


Table 3: Toxicity (as reported in Yang et al 2014, Cochrane Review)

\begin{tabular}{lcccc}
\hline & Cetuximab+Chemo & Chemo alone & Relative Risk & $\mathbf{9 5 \%} \mathbf{C l}$ \\
\hline & & & & $10.66-$ \\
acneiform rash & 11.2 & 0.3 & 37.37 & 130.95 \\
hypomagnesemia & 5.3 & 0.8 & 6.57 & $1.13-38.12$ \\
infusion reaction & 3.9 & 1.1 & 3.5 & $1.76-6.94$ \\
diarrhea & 4.8 & 2.3 & 2.1 & $1.26-3.48$ \\
hypokalemia & 6.3 & 3.6 & 1.74 & $1.02-2.99$ \\
febrile & & & & \\
neutropenia & 10.6 & 7.6 & 1.4 & $1.1-1.77$ \\
leukopenia & 58.1 & 42.7 & 1.36 & $1.17-1.58$ \\
\hline
\end{tabular}




\section{Figure legend}

Figure 1: relationship between EGFR expression, copy number and point mutations. Data obtained for provisional Lung Adenocarcinoma (left) and provisional Lung Squamous Carcinoma from the TCGA through cBioPortal

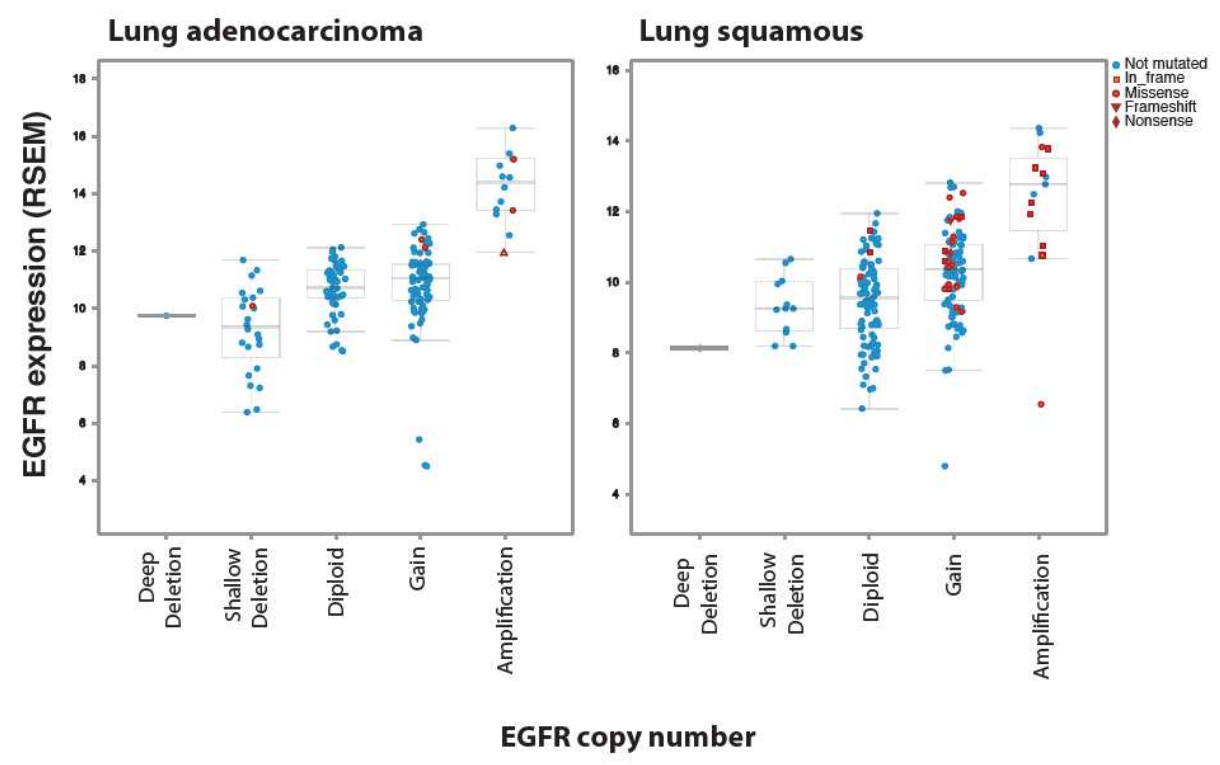

Figure 1 